\title{
Ventilation and Relative Humidity in Swedish Buildings
}

\author{
Thomas Alsmo, Catharina Alsmo \\ Library Research, Olten, Switzerland \\ Email: administrator@libraryresearch.eu
}

Received 1 July 2014; revised 28 July 2014; accepted 18 August 2014

Copyright (C) 2014 by authors and Scientific Research Publishing Inc.

This work is licensed under the Creative Commons Attribution International License (CC BY). http://creativecommons.org/licenses/by/4.0/

c) (i) Open Access

\section{Abstract}

An important factor for comfort ratio in the indoor environment and affecting human health and well-being is the relative humidity. Studies have shown that about $70 \%$ of the staff at Swedish offices, schools and kindergartens experiences that the air is too dry during the winter season. Studies show that the relative humidity in indoor environments influences the incidence of respiratory infections and allergies. Important factors for the air environment indoors is to limit the number of airborne particles, since these are conveyors of both bacteria and viruses, and to keep the humidity at a level above $40 \%$ and below $70 \%$, making the survival of viruses and bacteria minimized. Measurement results show that there is significant difference in the relative humidity during the winter season between the mechanically ventilated buildings with relative humidity levels below $10 \%$ than in buildings with natural ventilation. An important issue is how human health is affected by during longer periods and during much of the day live in environments with low relative humidity. Several researchers have noted that the incidence of respiratory infections increase during the winter when people are exposed to long periods of low humidity indoors. This means that the consequences of low humidity in the indoor environment should be considered and evaluated in a completely different way than is done today.

\section{Keywords}

Indoor Air Humidity, Ventilation, Hygiene and Health, Air Quality, Sick Building Syndrome (SBS), Indoor Environment, Indoor Temperature

\section{Project Description}

An important factor for the comfort ratio in the environment that affects both human health and well-being is the relative humidity. Studies have shown that approximately $70 \%$ of the staff at Swedish offices, schools and kin- 
dergartens experiences that the air is too dry during the winter season [1]. Studies show that the relative humidity in indoor environments influences the incidence of respiratory infections and allergies. Important factors for the indoor air environment are to

1) limit the number of airborne particles as they are conveyers of both bacteria and viruses and

2) to ensure that the humidity keeps a level above $40 \%$ and below $70 \%$, making the survival of viruses and bacteria minimized.

In epidemiological studies, the relationship between the number of respiratory infections and the relative humidity in offices, homes and schools has been investigated. The incidence of respiratory infections was found to be lower among people who work or live in environments with a relative humidity between $40 \%$ and $70 \%$, as opposed to those that live in environments with a relative humidity level below alternatively above this level. Regarding mite populations they are minimized when the relative humidity is below $50 \%$ and reaching a maximum number at $80 \%$. Most species of fungi cannot grow unless the relative humidity exceeds $60 \%$. Relative humidity also affects the rate of development of the formaldehyde, acids and salts from sulfur and nitrogen dioxide and the rate of ozone formation. Furthermore, there are indications that allergens, pathogens and harmful chemicals are influenced by the relative humidity indoors. A review of the relative humidity shows that the negative health effects can be minimized by maintaining a relative humidity above $40 \%$ and below $60 \%$. The effects of relative humidity on the biological and chemical factors are graphically summarized in Figure 1 . The shape and height of the bars in the figure indicate an increase or a decrease in power and provides no quantitative data. Most health effects increase in severity over $60 \%$ and/or less than $40 \% \mathrm{RH}$. The exceptions are the chemical interactions that consistently increase over $30 \%$, and the conditions that produce ozone, which is constantly increasing in severity with a decline in relative humidity. The shaded part of the diagram shows the approximate optimum middle zone to minimize adverse health effects related to the relative humidity and the adverse health and comfort effects of low relative humidity. A reduction in morbidity and possibly mortality due to influenza may be the most important beneficial result of an increase in relative humidity from low to intermediate [2]. The conditions for an "appropriate thermal climate" is a commonly formulated functional requirement and the temperature that can be accepted, must be assessed case by case. In Sweden, one needs typically expect to hold at least $+20^{\circ} \mathrm{C}$ in air temperature to the overall climate indoors is to become acceptable for sedentary work and with normal attire. With a mobile or physically more strenuous work, it is advantageous to have a lower temperature. Inconvenience and discomfort of cooling cannot be determined solely by the measurement of air temperature, since the experienced temperature will depend on several factors. Climate factors are air temperature, radiant temperature, air speed and humidity. Work intensity and attire are other factors that influence climate experience. High temperatures indoors are inherently linked to both the outdoor climate, building construction and the amount of heat generated by operating activities. In the office lighting and computer equipment are normally the heat sources that give the greatest heat gain. Air high moisture content in summer makes it harder to get rid of the body's excess heat. Buildings with for example a light blade, low ceiling heights, small rooms, poorly insulated roof structures, large windows without solar shading and air intakes in the sun causes the temperature to rise quickly indoors. Troublesome solar radiation through windows can be reduced with various types of solar shading. An externally placed foreclosure normally has the best effect. Approximate shielding ability is for curtains about $20 \%$, blinds between the glass $30 \%$ and awnings or exterior blinds about $60 \%$ [3].

Humidity, or the amount of water vapor in the air, has great significance for the experience of air. The humidity outdoors varies geographically in Sweden and between the different seasons. There are different dimensions to specify humidity, such as absolute or relative humidity. The mass of water vapor in a cubic meter of air is called absolute humidity and the unit $\mathrm{g}$ water $/ \mathrm{m}^{3}$. The absolute humidity is also sometimes referred vapor content, the water vapor density or density. The maximum amount of water vapor depends on the air temperature the warmer it is the more water vapor the air holds before condensation occurs, see Figure 2. Relative humidity is usually expressed in percentage. If the amount of water vapor is maximum at a given temperature is the saturation and the relative humidity is $100 \%$. In fog with maybe a little light drizzle humidity is $95 \%-100 \%$. The relative humidity is strongly related to temperature. As the air warms up the relative humidity declines and in the winter, when the cold outdoor air is taken in and warm up indoors, the humidity is often low. Many people will then have problems with dry air pipes. If the temperature falls rather than rises, the relative humidity increases which occurs in cool basements, where we know that it is inadvisable to store materials that absorb moisture, such as books and clothes [4]. All measurements of humidity assume that there is an upper limit to the humidity, which depends on temperature and pressure. If we then either add more water vapor (humidity) or lower the gas 
DECREASE IN BAR WIDTH

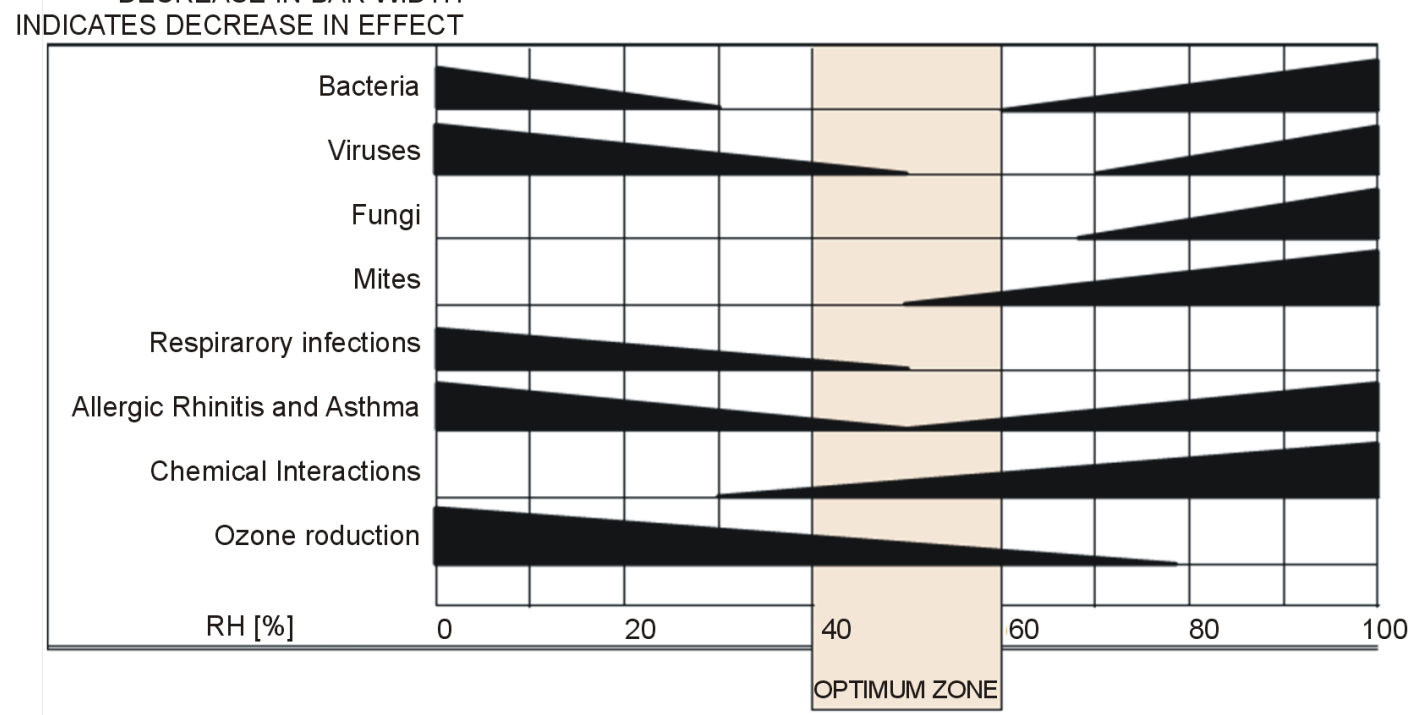

Figure 1. Optimal zone, $40 \%$ - $60 \%$ relative humidity to minimize adverse health effects from airborne impurities.

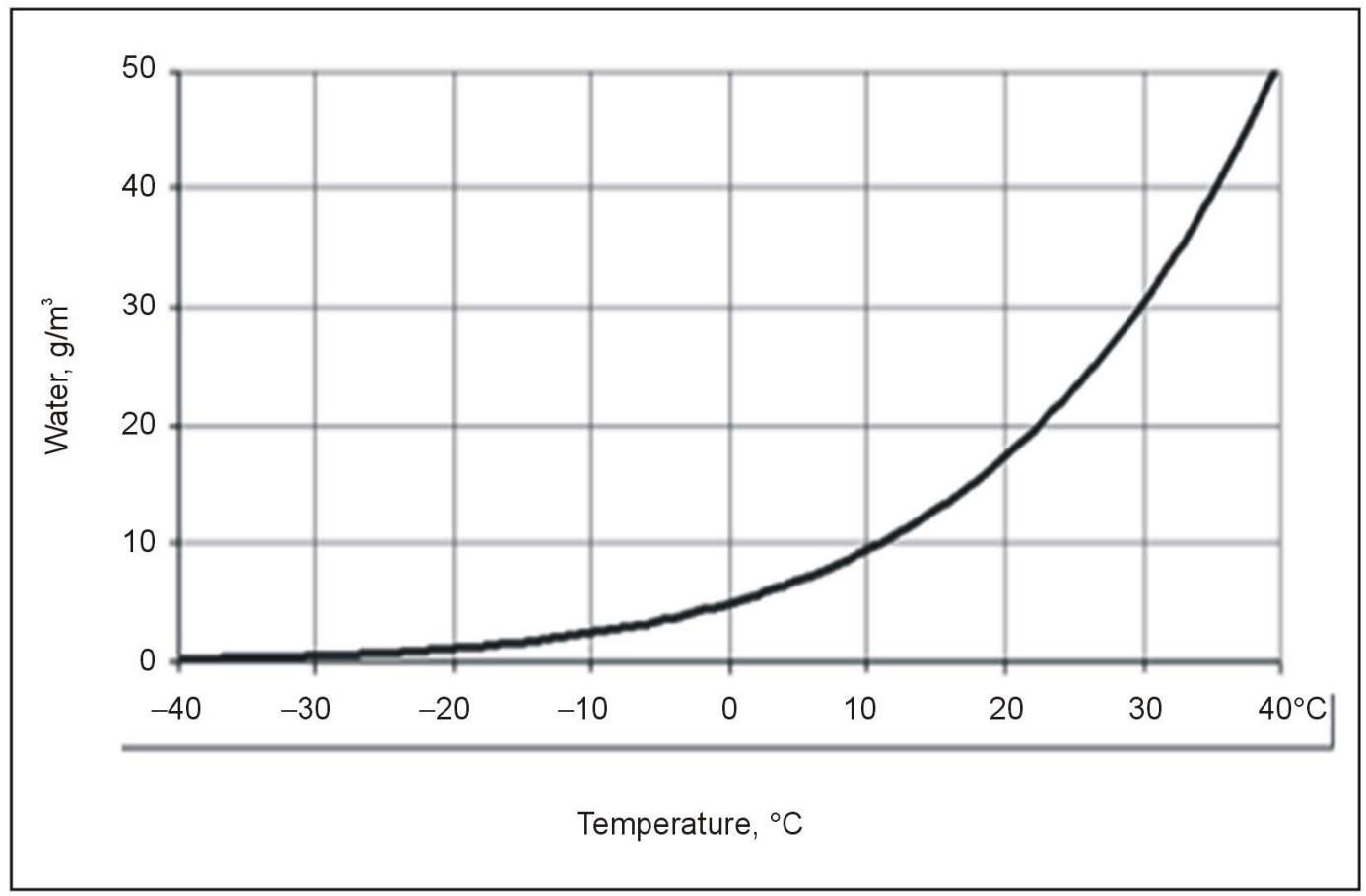

Figure 2. The graph shows the relationship between saturation vapor content $\left(\mathrm{g} / \mathrm{m}^{3}\right)$ and temperature $\left({ }^{\circ} \mathrm{C}\right)$.

temperature, the amount of water vapor will eventually exceed this maximum and the excess precipitates out as drops of water $=$ condensation. The measured value can be expressed in two ways:

- Absolute humidity is the water mass per unit volume (grams of water per cubic meter) or per unit mass of air (grams of water per kilogram of air).

- Relative humidity is the actual amount of moisture expressed as a percentage of the saturation pressure at that temperature.

The relative humidity can vary greatly throughout the day and indoor air tends to be quite dry for people when humidity is below 30\%. Dry air tends to be more common in colder climates because of the condensation will 
not fit in the chilly air [5]. The relative humidity in indoor environments, within the range of normal indoor temperatures of $19^{\circ} \mathrm{C}$ to $27^{\circ} \mathrm{C}$, there are both direct and indirect effects that affect health and comfort. To minimize as many negative health effects as possible it is indicated that the relative humidity should be between $40 \%$ and $60 \%$. Both at low and high relative humidity physical discomfort can arise because the relative humidity has a direct impact on how the comfort is perceived [6]. Extremely low levels below 20\% can cause eye irritation [7] [8], while moderate or high levels of humidity have been shown to reduce the severity in people with asthma [9]. Several reports, based on the experiences of doctors with patients, where these patients have complained of dryness of the nose and throat where there is low relative humidity. These doctors have argued that the relative indoor humidity should be maintained above $30 \%$ to $40 \%$ to prevent drying of the mucous membranes and to maintain adequate nasal mucus transport and ciliary activity [10]-[13]. Relative humidity can directly affect the mucous membranes in people with bronchial constriction, rhinitis, or cold and flu related symptoms. One study showed that steam capacity in the anterior nasal decreased in rhinitis [14] and another study found a slight decrease in moisture capacity in the noses of four people with atrophic rhinitis compared with 22 healthy subjects [15]. Relative humidity can also affect bronchial mucus of nasal obstruction if it leads to mouth breathing. In an in vitro study on the effect of relative humidity on the viscosity of bronchial mucus was found a two-fold decrease in viscosity when the relative humidity was $100 \%$ compared with $60 \%$ [16]. Relative humidity also has a significant negative direct effect on health when high humidity is combined with high temperature. This combination reduces the rate of evaporative cooling of the body and can cause significant discomfort or lead to heat stroke, exhaustion and possibly death.

Diseases are transmitted by airborne pathogens or through direct contact with pathogens, which live on hard surfaces such as furniture and fixtures, or by touching an infected person. Low relative humidity has been shown to improve survival of rhino virus and influenza virus [17] and human rota virus (a cause gastroenteritis) [18] on hard surfaces. Experimental studies on the survival of pathogens in the air with different relative humidity figures and epidemiological studies on respiratory infections suggest that the relative indoor humidity affects the incidence of infectious diseases transmitted by airborne pathogens. The presence of airborne contagious distributions of infectious diseases indoor is also influenced by the number of infected humans producing contaminated aerosols, the number of susceptible, the exposure time, the degree of aeration, settling velocity of contaminated aerosols and survival of pathogens attached to the aerosols [19]. Low relative humidity can increase the incidence of infectious aerosols produced by coughing or expiratory. Rapid evaporation in dry air can cause the diameter of some aerosols to fall below the size limit for a particle to remain in suspension, while at higher relative humidity, the same aerosol reaching the floor before sufficient evaporation occurs [20]. A relative humidity of $50 \%-70 \%$ has only a minor effect on aerosol size and subsequent sedimentation ratio [21]. Depending on the initial composition and size of the aerosol, its size can rapidly increase due to water absorption when the relative humidity of $80 \%$ to $90 \%$, resulting in higher sedimentation rates [22]. An increase in the amount of suspended aerosols, due to a low relative humidity is more likely to have an effect on health than the reduction of these during periods of very high relative humidity. Experimental studies have shown that the relative humidity is an important factor for the survival of airborne pathogens. Relative humidity affects the survival by altering the integrity of the cell wall or the viral coat [23].

- BACTERIA: Bacteria that cause pneumonia, tuberculosis, Q fever, brucellosis (budgerigars fever), anthrax and Legionnaires' disease are transmitted in the air [24]. However, it is little known about the direct effect of relative humidity on airborne living pathogenic (disease-causing) bacteria or its infectivity. On the other hand the effect of relative humidity of non-pathogenic bacterial species such as E. coli, has been extensively studied. In general, a relative humidity between $40 \%$ - $60 \%$ is more lethal for airborne non-pathogenic bacteria than low or high humidity [21]. Some studies on pathogenic or closely related bacterial species suggest that pathogenic bacteria concerning the relative humidity is similar to that of the non-pathogenic strains. Mycoplasma pneumoniae is an airborne transmitted bacterium that can cause pneumonia and other serious respiratory infections. Tests of non-pathogenic Mycoplasma species suggest that mycoplasmas survive longer during exposure to either high or low relative humidity [25]. A similar pattern of survival is non-pathogenic species of Streptococcus [26]. Serratia mrarcescens, an opportunistic bacterium that causes respiratory infections, is least productive during exposure up to $50 \%$ relative humidity and reaches the maximum viability over $80 \%$ [27]. High relative humidity of $70 \%-80 \%$ is also favourable for Brucella suis [28] and Staphylococcus albus [29].

- VIRUS: The large airborne transmissible viruses are influenza, measles, herpes, chicken pox, rubella, the 
adenovirus (cause of acute respiratory illness with flu-like symptoms), and coxsackie virus (the cause of some rashes and fever) [19] [30] [31]. Respiratory syncytial virus (RSV) and parainfluenza virus (both of which cause flu-like symptoms) and rhino virus (the common cause of cold syndrome) can also be airborne, but the incidence of infections caused by airborne transmission is considered to be very low compared to the direct contact [19] [32]. The effect of moisture on viability of the virus depends on viral molecular structure. High relative humidity tends to favour the survival of viruses composed entirely of nucleic acids and proteins, whereas lipid-containing viruses prefer low relative humidity [33]. Lipids are in chemistry, a collective name for a large group of substances consisting of fats and fat-like substances. Adeno virus and coxsackie virus prefer relative humidity above 70\% [34] [35]. Measles, influenza, herpes varicella and rubella viruses survive longer when exposed to relative humidity below 50\%. Mass Vaccination Program of measles and rubella has decreased in importance for public health, while infections caused by adeno virus and coxsackie virus normally occur at a low incidence in the population. Consequently, the influenza virus is the main airborne transmitted viral disease. Several laboratory studies have examined the relationship between relative humidity and the survival of flu viruses and disease transmission. Independent tests show decreased viability of influenza viruses carried by aerosols when there is a higher relative humidity. It has been found that the inactivity of viruses sharply increased at a relative humidity of $40 \%$ and upwards, and also the percentage of viable influenza virus decreased as the relative humidity increased from $35 \%$ to $81 \%$ [36] [37]. In other studies of the relative humidity of airborne transmission of influenza in mice, uninfected mice were placed in cages adjacent to cages with mice infected with influenza. Body contact between the mice in the different cages was not possible. The effect of relative humidity was determined after adjustment for the dilutive effect of changes in ventilation. The infection rate decreased when the relative humidity increased from $47 \%$ to $70 \%$. The results of these experiments suggest that influenza infection is highest in environments with relative humidity below $40 \%$ and decreases rapidly when the relative humidity exceeds $40 \%$ to $50 \%$ [38]. In further studies it was found that the rate of infection in mice exposed to aerosols containing influenza virus increased both below $40 \%$ and above $55 \%$ RH and was minimized during exposure to $55 \%$ relative humidity. Schaffer et al. [39] [40] found similar results. Aerosols of influenza virus in cultured human cells were exposed to a relative humidity between $20 \%$ and $80 \%$. The viral survival was highest for exposure less than $20 \%$, fell to a minimum after exposure to a relative humidity between $40 \%$ and $60 \%$, and increased again at exposure to $70 \%-80 \% \mathrm{RH}$, although the survival rate at $80 \%$ was lower than that at a relative humidity below $20 \%$. Consequently, it is possible that the risk of infection by the influenza virus shows an increase at both high and low relative humidity levels. Variations in the experimental results may also depend on different methods for production of aerosols.

In summary the available data on bacterial and viral survival, at varying relative humidity, indicate that there is a level, from $40 \%$ up to $70 \%$, which minimizes the combined survival or infectivity of these organisms.

- MITES: They are the main cause of allergies in house dust. Laboratory studies have established that the populations of the ordinary house dust mite, Dermatophagoides pteronyssinus, reaching a maximum size during exposure up to $80 \% \mathrm{RH}$ [41]. Several field studies have found parallels, the number of mites in homes and seasonal changes in relative humidity in the indoor environment. In addition, mite populations were almost eliminated in the winter when the relative humidity dropped below $40 \% / 50 \%$ level. The results suggest the possibility of a direct causal link between higher average relative humidity indoors and allergies due to dust mites. It must be noted that the number of mites per gram of dust were consistently higher in the patients' houses compared to the control group [42]-[45].

- FUNGI: Microorganisms that are known to cause allergic reactions such as asthma or rhinitis are of the genera Alternaria, Cladosporium, Aspergillus, Mucor, Rhizopus, and Merulius [46]. Several fungi such as Aspergillus can also cause hypersensitivity diseases in individuals who do not normally suffer from allergies [47]. Most fungi require relative humidity of over $75 \%$ in order to grow. Accordingly, actively growing fungal populations are usually an outdoor problem, while indoors it is limited to areas such as kitchens, bathrooms, walls and window frames that are subject to frequent condensation due to high local relative humidity rate [46]. Several chemicals that may be found in indoor air interact with the water vapor and may form respiratory problems and skin irritations. Health problems that can be attributed to chemical interactions with moisture are probably less widespread than the problems caused by biological interactions. However, chemical interactions can be significant in buildings with a high percentage of formaldehyde-containing materials, gas stoves for cooking or geographically located close to outdoor sources of water reactive air pollutants. 
- FORMALDEHYDE: Low exposure to formaldehyde has adverse health effects such as irritation to skin, eyes and throat, breathing difficulties and allergies [48]. In a climate chamber the degree of degassing, formaldehyde from particle board, was examined and where it was found that the formaldehyde concentration in the air was directly proportional to the relative humidity at a given temperature. Formaldehyde levels increased from 0.5 to $0.6 \mathrm{mg} / \mathrm{m}^{3}$ at $30 \% \mathrm{RH}$ to 1.2 to $2.0 \mathrm{mg} / \mathrm{m}^{3}$ at $70 \% \mathrm{RH}$ [49]. In a study of formaldehyde levels in 20 homes it was found a statistically significant correlation between relative humidity and indoor formaldehyde concentration in the air [50].

- SULPHUR AND NITROGEN DIOXIDES: Sulfur dioxide acts as a respiratory irritation in healthy subjects and causes bronchial constriction in sensitive individuals, such as asthmatics at concentrations as low as 0.1 ppm [51]. Sulphur dioxide interacts with water vapor to form aerosols containing the sulfate salts and sulfuric acid, which is more irritating than the sulfur dioxide itself [52]. Nitrous oxide (laughing gas) and nitric acid are formed indoors by the interaction of water vapor with nitrogen dioxide from unvented gas stoves and heaters. Both acids are believed to play an etiological role in the development of respiratory illness and reduced lung function [53].

- OZONE: Ozone levels indoor are amplified by the low relative humidity while high relative humidity reduces ozone levels by accelerating the adsorption of ozone molecules on surfaces indoors [54]. Ozone is a strong oxidant and different exposure intervals are likely encountered in homes and are irritating to the eyes as well as the mucous membranes [55].

\section{Measurements}

This study includes measurements of relative humidity (RH) \% and air temperature ${ }^{\circ} \mathrm{C}$ for two building types, one with natural ventilation and one with mechanical ventilation. Measurements have been conducted at six sites in Sweden; southern Götaland and eastern Svealand, west Svealand, southern Norrland, northeast and northwest Norrland, which means a geographical distribution of the Swedish climate zones. The purpose of the measure study is to evaluate if a difference can be identified regarding relative humidity in these two different types of buildings because of the difference in ventilation solutions. The basis for the indoor environment is the climate outdoors and therefore the measurements are also carried out in ambient air adjacent to the buildings. The instruments used in this study are Testo 175 data logger. These temperature loggers have two channels, one for relative humidity and air temperature respectively and an internal sensor along with an external sensor connection. The stored readings are evaluated using both software and programming and readout of the logger is made to the computer via a USB connection. The measurements were carried out preferably during the period from January 3 to March 10, 2014. A deeper study took place on the spot in southern Norrland where measurements started already on December 21, 2013. The purpose is to gain insight into the relationship of the school when the activity is not conducted (Christmas holidays) and during climate conditions with reduced air flow.

\section{Results of the Measurements}

From the results of the measurements it is clear that there are large differences in the relative humidity during the measurement period. Generally it can be identified a lower humidity prevailing in the mechanically ventilated buildings, with a mean $\mathrm{RH}=23.1 \%$ compared with $27.3 \%$ in buildings with natural ventilation. The difference is 4.2 percentage points, and it should be stressed that 4.2 to 23.1 , after all, is a percentage of the moisture ratio on the entire $18.2 \%$. Table 1 and Figure 3 show the highest recorded average and lowest measured value from each site. The results in Table 1 and Figure 3 indicate that the mechanical ventilation system generally provides a lower relative humidity in buildings than the natural draft. For a greater insight into how the relative humidity is affected by the ventilation system the results are studied from southern Norrland, the climate zone which is situated in central Sweden, and thus can be considered, from the Swedish climate point of view, a middle zone. The measurements cover the period from 20 December 2013 to 7 March 2014. The results of the measurements are shown in Figure 4, A: levels in the mechanically ventilated building, B: levels of the building with natural ventilation and C: outdoor levels. As shown in Chart $C$ of Figure 4 is a period with regular temperature level out, below freezing from on or about 10 January and until the end of January. Diagram A and B, shows that the humidity drops significantly during this cold spell. Figure 5 and Figure 6 show the period from 10 to 24 January 2014 for these two buildings. The study was initiated on January 10, a Friday, with operations in the buildings. Then, over the weekend of 11 and 12 January lasted no activity, to those with the subsequent 
five working days 13 to 17 January with activity and then again holidays on 18 and 19 January with no activity. In the building with mechanical ventilation, the air flow is reduced to $25 \%$ of its capacity during weekends and evenings and nights to be in full operation again at 5 o'clock in the morning. As seen the relative humidity decreases during the daytime to rise at night and weekends. The relative humidity thus varies significantly between day and night, to the detriment of the level prevailing during the day with lows of $10 \%-15 \%$. The level of natural ventilation building is not less than $15 \%$ and generally has a more consistent level than that prevailing in the

Table 1. Measured levels, relative humidity (RH) in $\%$ and the air temperature in ${ }^{\circ} \mathrm{C}$ at six different locations in Sweden, during the measurement period 3 January to 7 March 2014.

\begin{tabular}{|c|c|c|c|c|c|c|}
\hline & $\begin{array}{c}\text { Mechanical } \\
\text { ventilation, RH \% }\end{array}$ & $\begin{array}{c}\text { Mechanical } \\
\text { ventilation, }{ }^{\circ} \mathrm{C}\end{array}$ & $\begin{array}{c}\text { Natural } \\
\text { ventilation, RH \% }\end{array}$ & $\begin{array}{c}\text { Natural } \\
\text { ventilation, }{ }^{\circ} \mathrm{C}\end{array}$ & $\begin{array}{l}\text { Outdoor, } \\
\text { RH \% }\end{array}$ & Outdoor, ${ }^{\circ} \mathrm{C}$ \\
\hline \multicolumn{7}{|l|}{$\begin{array}{l}\text { SOUTH } \\
\text { GOTALAND }\end{array}$} \\
\hline Highest & 31.1 & 22.1 & 41.5 & 26.1 & 99.9 & 5.8 \\
\hline Avarage & 20.3 & 19.61 & 25.25 & 22.28 & 88.89 & -5.87 \\
\hline Lowest & 11.4 & 16.3 & 10.4 & 21.1 & 67.6 & -7.9 \\
\hline \multicolumn{7}{|l|}{$\begin{array}{l}\text { EAST } \\
\text { SVEALAND }\end{array}$} \\
\hline Highest & 38.6 & 25.2 & 43.7 & 25.8 & 99.9 & 14.3 \\
\hline Avarage & 27.52 & 21.93 & 32.14 & 20.95 & 89.65 & -0.42 \\
\hline Lowest & 30.3 & 17.9 & 21.6 & 19.1 & 31.2 & -13.7 \\
\hline \multicolumn{7}{|l|}{$\begin{array}{l}\text { WEST } \\
\text { SVEALAND }\end{array}$} \\
\hline Highest & 32 & 23.1 & 43.9 & 25.9 & 99.9 & 13.8 \\
\hline Avarage & 21.64 & 22.14 & 25.3 & 22.5 & 88.65 & -0.72 \\
\hline Lowest & 8.7 & 21.4 & 12.8 & 20.1 & 30 & -15.1 \\
\hline \multicolumn{7}{|l|}{$\begin{array}{l}\text { SOUTH } \\
\text { NORRLAND }\end{array}$} \\
\hline Highest & 30.6 & 23.8 & 37 & 21.9 & 99.9 & 9.9 \\
\hline Avarage & 21.54 & 20.85 & 24.86 & 19.94 & 91.37 & -0.52 \\
\hline Lowest & 8.9 & 19.2 & 15 & 19.2 & 51.9 & -14.5 \\
\hline \multicolumn{7}{|l|}{$\begin{array}{l}\text { NORTHEAST } \\
\text { NORRLAND }\end{array}$} \\
\hline Highest & 33.9 & 27.3 & 36 & 22.3 & 99.9 & 10.5 \\
\hline Avarage & 22.92 & 25.51 & 26.35 & 20.65 & 90.83 & -2.93 \\
\hline Lowest & 14.6 & 23.3 & 16.9 & 19.3 & 37.8 & -19.9 \\
\hline \multicolumn{7}{|l|}{$\begin{array}{l}\text { NORTHWEST } \\
\text { NORRLAND }\end{array}$} \\
\hline Highest & 31.1 & 22.1 & 41.8 & 24.1 & 99.9 & 7.3 \\
\hline Avarage & 20.53 & 19.67 & 25.4 & 22.22 & 87.89 & -5.53 \\
\hline Lowest & 10.4 & 16.3 & 12 & 21.1 & 55.5 & -27.9 \\
\hline $\begin{array}{l}\text { All } \\
\text { measurement }\end{array}$ & $\begin{array}{c}\text { Mechanical } \\
\text { ventilation, RH \% }\end{array}$ & $\begin{array}{c}\text { Mechanical } \\
\text { ventilation, }{ }^{\circ} \mathrm{C}\end{array}$ & $\begin{array}{c}\text { Natural } \\
\text { ventilation, RH \% }\end{array}$ & $\begin{array}{c}\text { Natural } \\
\text { ventilation, }{ }^{\circ} \mathrm{C}\end{array}$ & $\begin{array}{c}\text { Outdoor, } \\
\text { RH \% }\end{array}$ & Outdoor, ${ }^{\circ} \mathbf{C}$ \\
\hline Highest & 38.6 & 27.3 & 43.9 & 26.1 & 99.9 & 14.3 \\
\hline Avarage & 23.11 & 21.54 & 27.33 & 21.92 & 78.37 & -4.08 \\
\hline Lowest & 8.7 & 16.3 & 10.4 & 19.1 & 30 & -27.9 \\
\hline
\end{tabular}




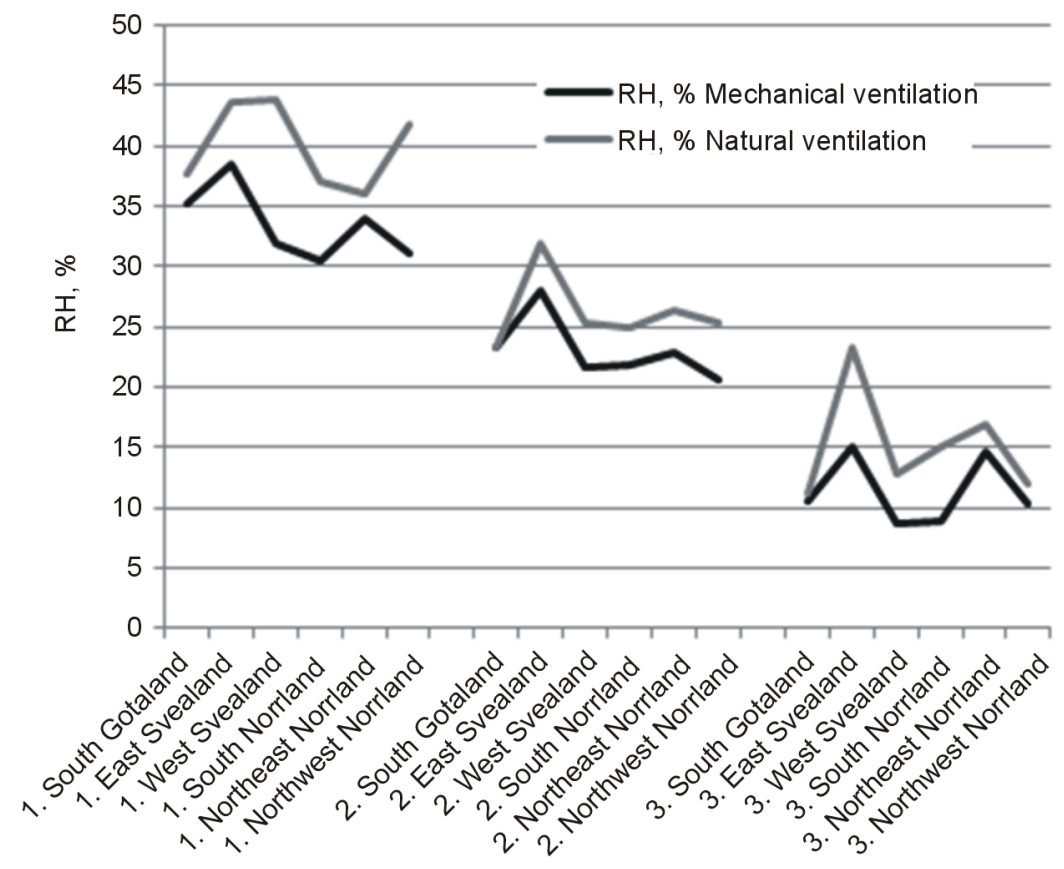

Figure 3. Measured levels of relative humidity (RH) \%, during the measurement period: 3 January to 7 March 2014 in six different locations in Sweden. The grouping at different locations: Group 1: The highest measured value; Group 2: Mean; Group 3: The lowest measured value. In general it can be identified that the relative humidity is lower in the mechanically ventilated building (black graph in the charts) in comparison to the building with natural ventilation (grey graph).

building with mechanical ventilation. Notably, the level rises during the day which means that the air is susceptible of the additional moisture that the dwellers of the building add, which is not possible in the mechanically ventilated building, see Figure 7 and detailed study Figure 8. To evaluate whether the same relationship exists between mechanically ventilated buildings and buildings with natural ventilation at other places, the same analysis were conducted there. The climatic conditions outdoors in cold temperature should be equivalent to an appropriate analysis to be made, which means that the measurement dates assigned to some extent differ between the various locations. As shown by the graphs in Figure 9 on the same basis at all places the humidity drops in the morning hours and in the morning. Lower levels prevail during daytime in the mechanically ventilated buildings than during the night, which is the opposite of what happens in buildings with natural ventilation. Regarding temperature, the building with the mechanically ventilated system in northeast Norrland stands out with an average temperature of $25^{\circ} \mathrm{C}$. This indicates that the temperature within the zone range from $19^{\circ} \mathrm{C}$ to $26^{\circ} \mathrm{C}$ indoors, have less impact wiping out of the air than the problems that the mechanical air flows cause. All average values

- Temperature, see Figure 10

- Relative humidity (RH), see Figure 11

Results from this study show that a major reason for the low humidity rates prevailing in indoor environments is high air flows caused by mechanical ventilation systems.

\section{Conclusions}

An important issue is how human health is affected by during longer periods and for much of the day staying in environments with low relative humidity. Several researchers have noted that the incidence of respiratory infections increase during the winter when people are exposed to long periods of low humidity indoors [33] [36] [56]. Nine epidemiological studies have provided further information on this hypothesis. Eight of these studies examined the effect of increased relative humidity from low to middle and in one study, the incidence of respiratory infections in homes with high versus middle relative humidity. Gelperin [57] studied the relationship 


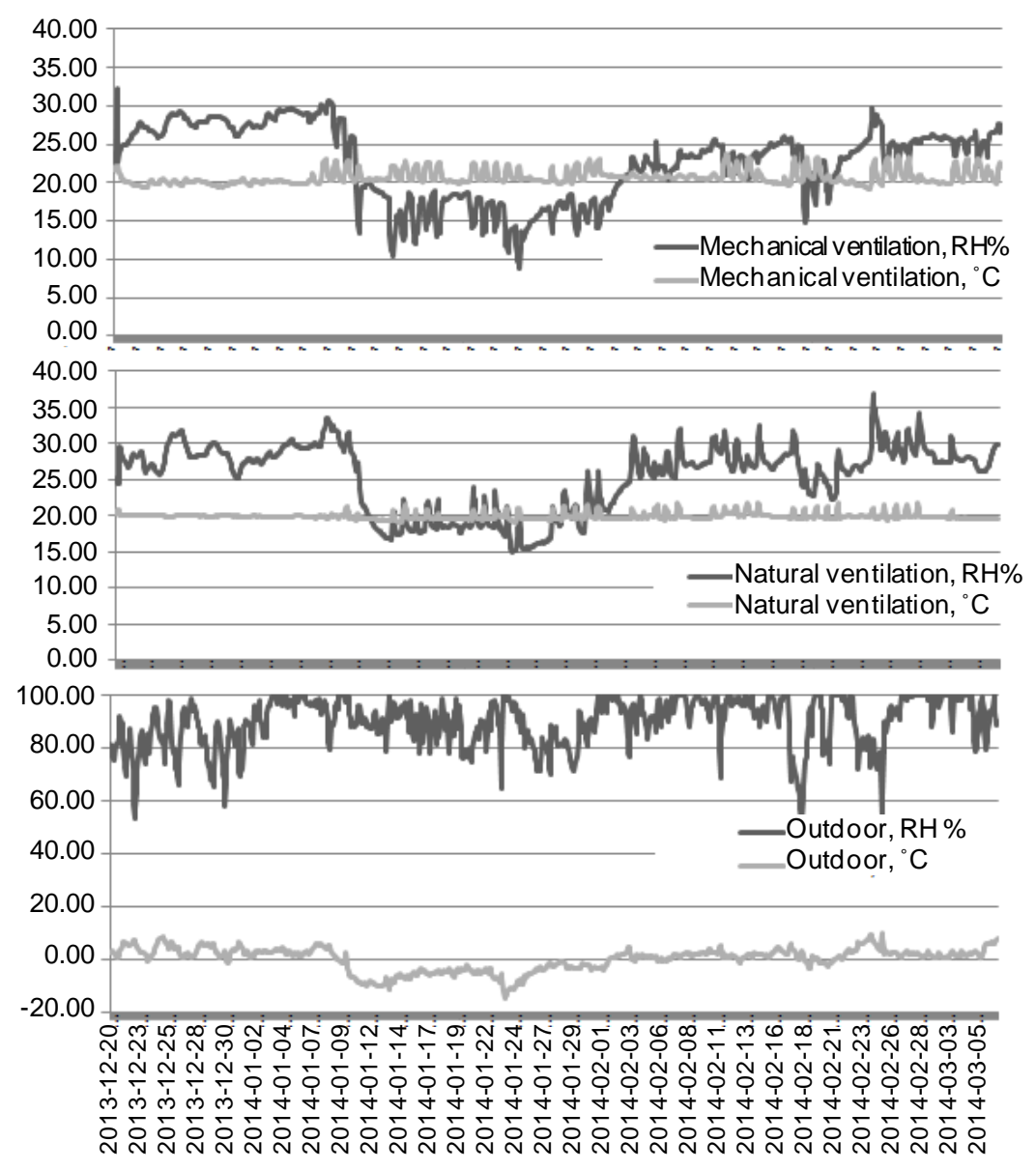

Figure 4. Measurement of humidity and air temperature in two buildings and out, geographically located in southern Norrland. A. Levels, humidity, RH \% and air temperature, ${ }^{\circ} \mathrm{C}$ in the mechanically ventilated building; B. Levels, humidity, $\mathrm{RH} \%$ and air temperature, ${ }^{\circ} \mathrm{C}$ in buildings with natural ventilation; C. Outdoor levels humidity, $\mathrm{RH} \%$ and air temperature, ${ }^{\circ} \mathrm{C}$. Measurement period December 20, 2013March 7, 2014.

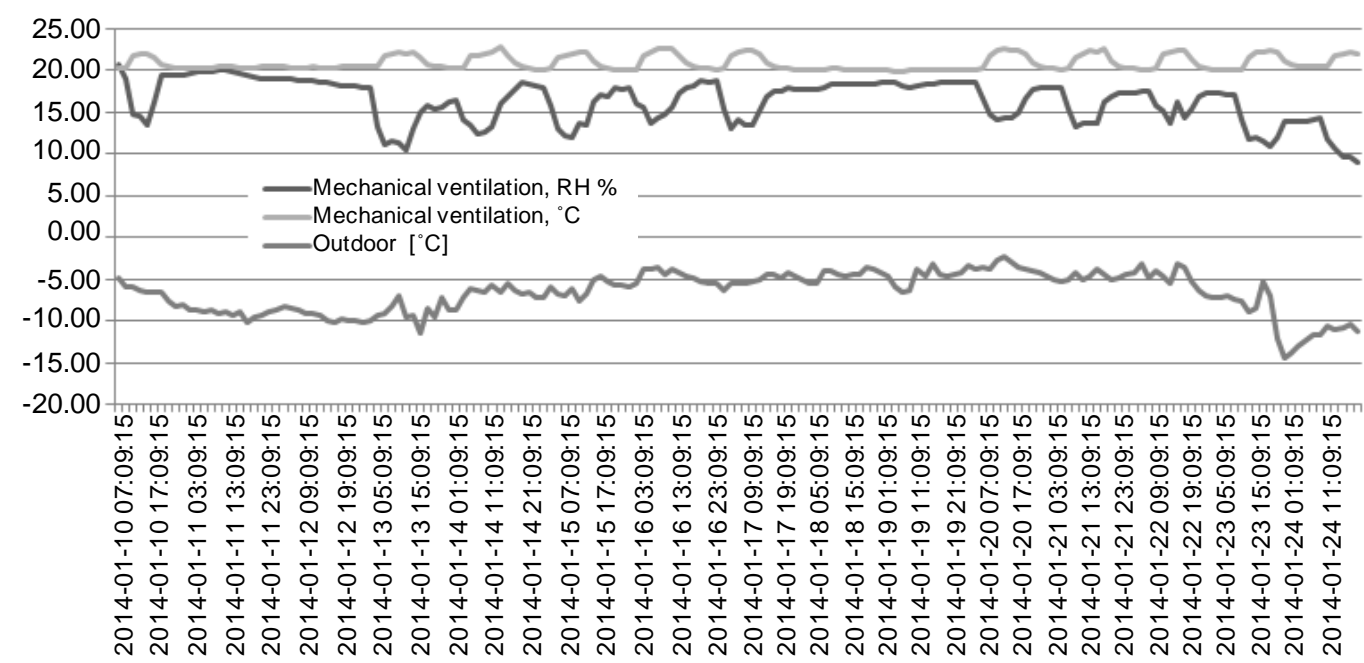

Figure 5. Levels humidity, RH \% and air temperature, ${ }^{\circ} \mathrm{C}$ in the mechanically ventilated the building and the outdoor air temperature, the measurement period 10 to 24 January 2014. 


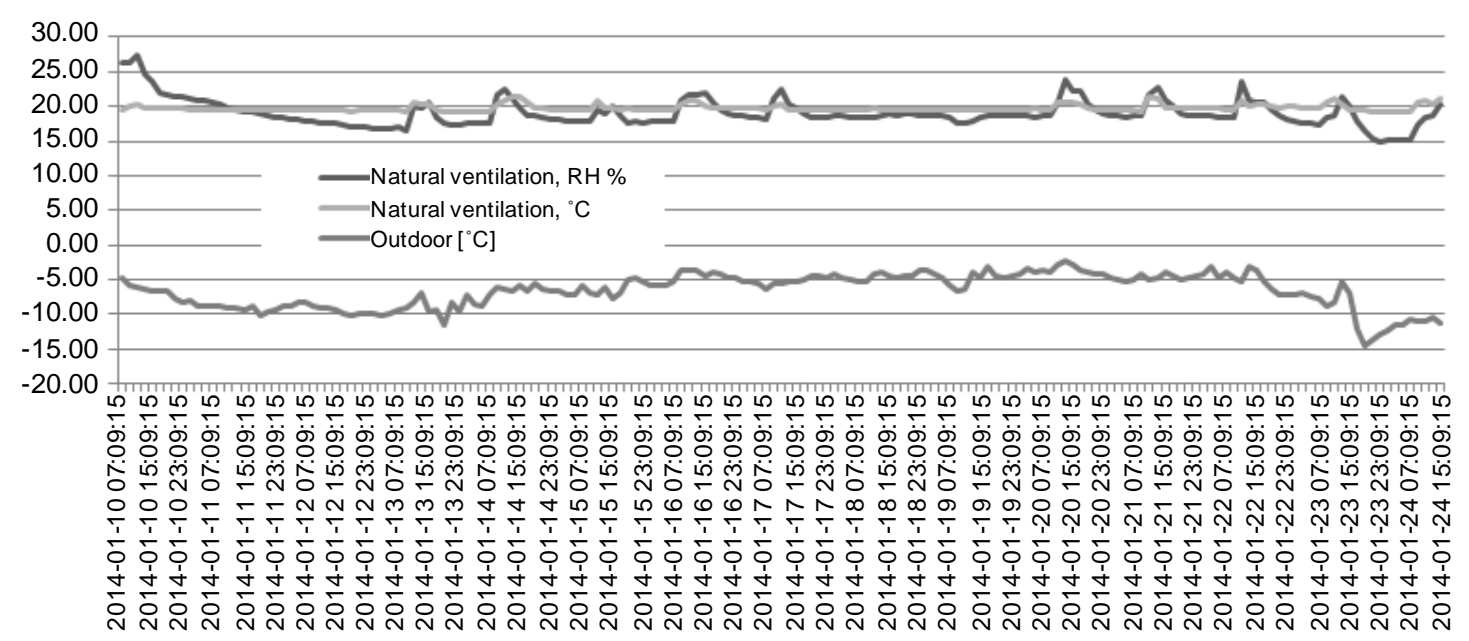

Figure 6. Levels, humidity, $\mathrm{RH} \%$ and air Temperature, ${ }^{\circ} \mathrm{C}$ of the building with natural ventilation, the measurement period 10 to 24 January 2014.

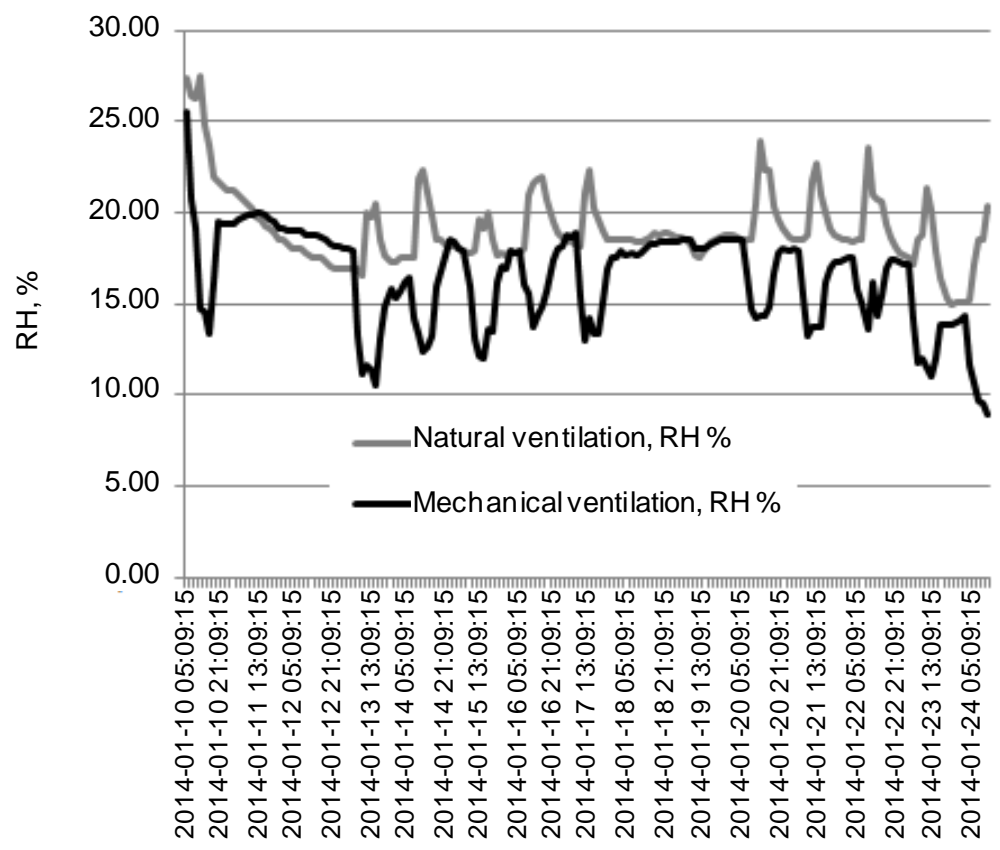

Figure 7. Measurement results of humidity, RH (\%), the measurement period 10 to 24 January 2014 in the building with mechanical ventilation and in buildings with natural ventilation. Of the graphs shows that the humidity varies during the daytime when the activity going on in the buildings and to the detriment of the building with mechanical ventilation design.

between relative humidity indoors and incidence of respiratory illness among 800 army recruits in two barracks, one of which was damp. The relative humidity was $20 \%$ on average in the non-humidified barracks and $40 \%$ in the barrack which was moistened. There were $8 \%$ fewer upper respiratory infections among soldiers in the damp barrack between October and December and 18\% fewer infections between January and March compared to recruits in barracks without humidification. Sale [58] found a significant reduction of respiratory infections in children attending a moister school. Ritzel [59] noted a reduction in colds, sneezing, sore throat and fever in preschool children after increasing the average relative humidity from $40 \%$ to $49 \%$. Several studies have used the absence as an estimate of respiratory infections, because about $50 \%$ of absences from school or work are caused by viral respiratory diseases [60]. The study by Green [61] combined data for 11 years from 12 schools 


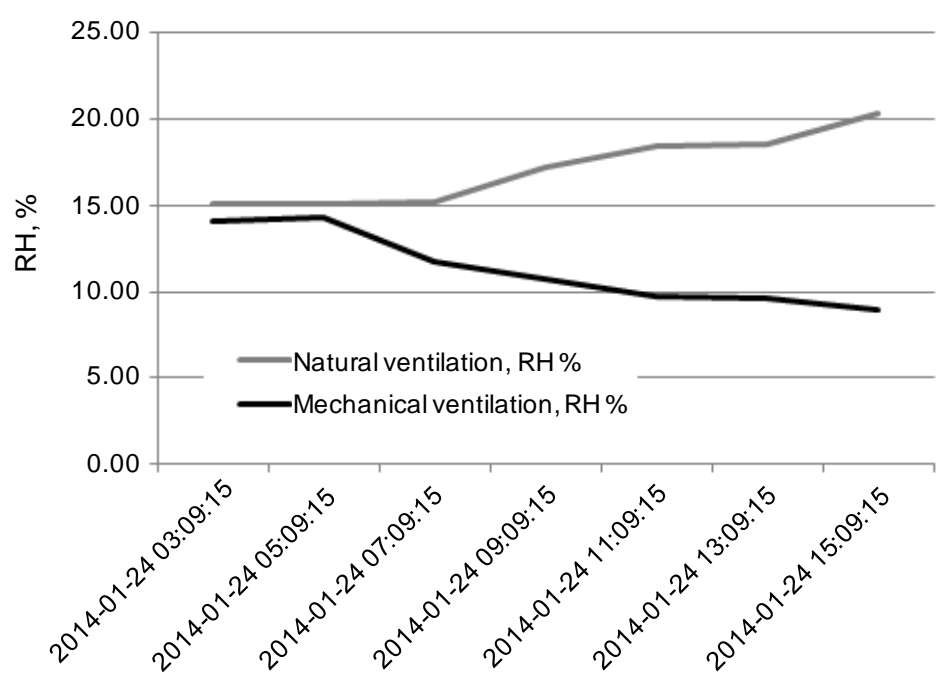

Figure 8. Measurement results of humidity, RH (\%), measurement period January 24, 2014, in the same buildings as in Figure 7, one with mechanical ventilation and a natural draft. The graphs show that the humidity is different during the daytime. In natural ventilation building boosts the level unlike the situation in the mechanically ventilated building where the level falls further from already low levels. There is activity in both buildings during the day, which should bring the air moisture, but as shown by the black graph, building with mechanical ventilation, decreases the level instead. The only explanation is that the ventilation flow was increased from $25 \%$ to $100 \%$ efficiency.

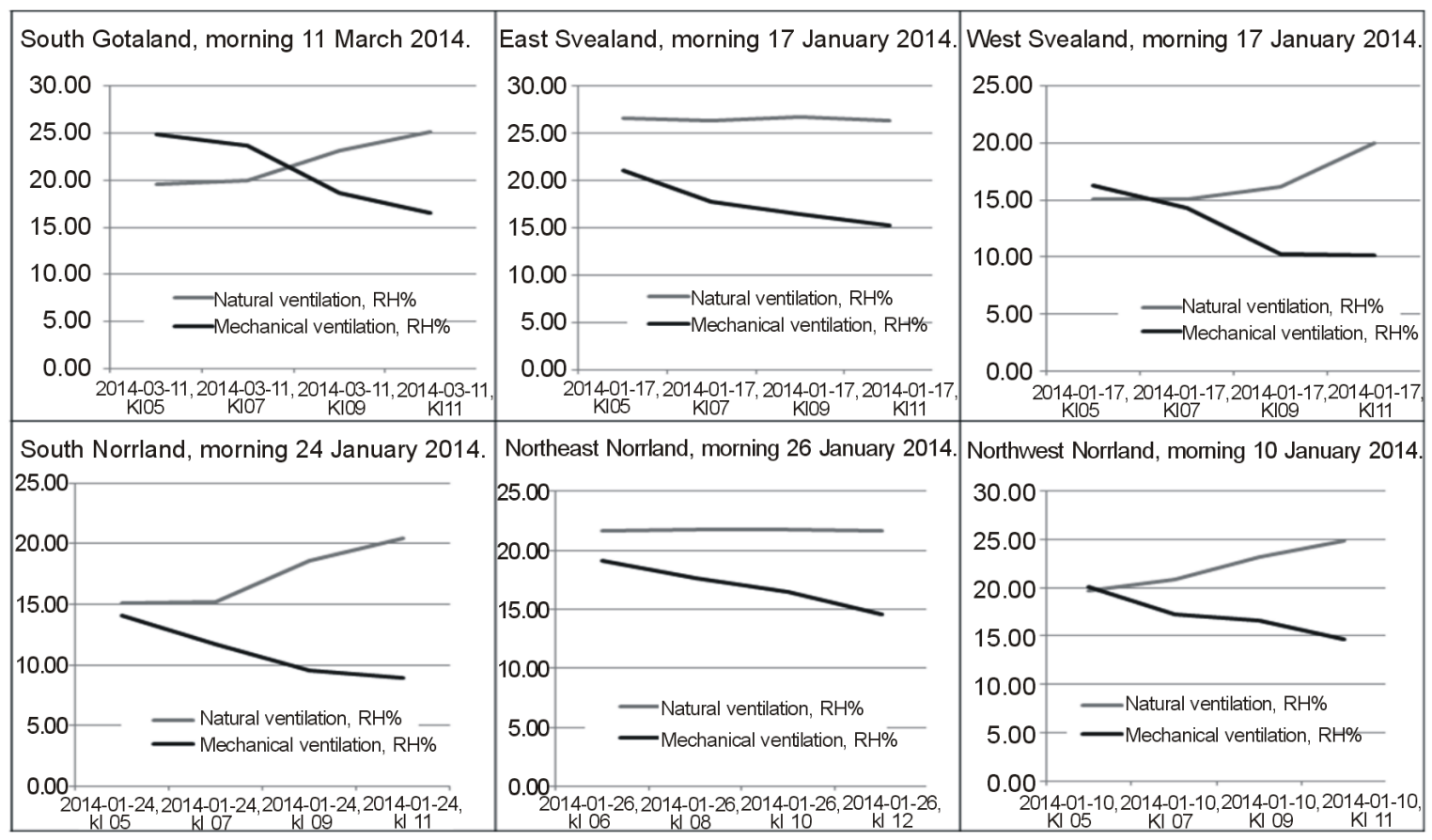

Figure 9. Measurement results of humidity, RH (\%) at all sites included in this study, which was conducted in measurement. Of the graphs shows that the humidity is different in the daytime; in natural ventilation buildings raised level, unlike the situation in the mechanically ventilated buildings, where the level instead fall further. There is activity in both buildings during the day, which should bring the air moisture, but as shown by the black dots in the diagrams, the level instead of these buildings. The only explanation for this is that the ventilation flow was increased from 0 or reduced flow rates to $100 \%$ flow efficiency. 


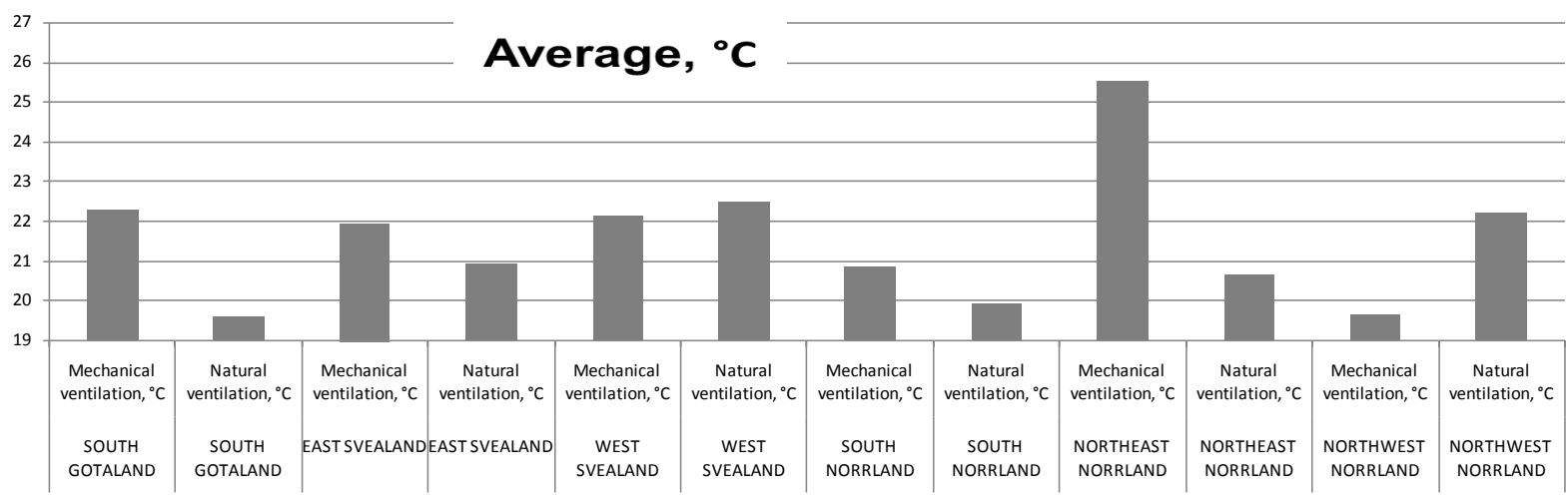

Figure 10. Average value, measured temperature levels in the buildings included in this measurement study.

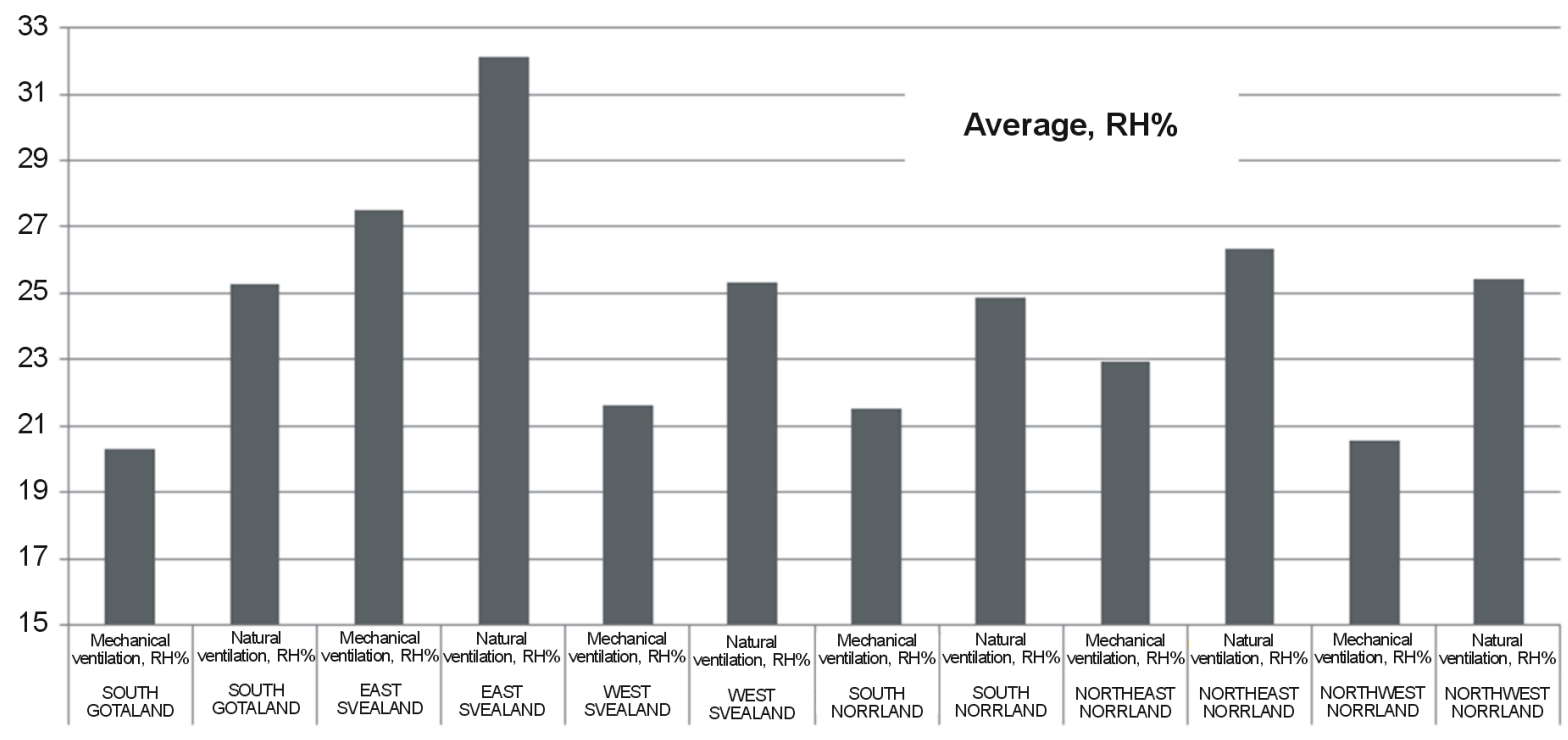

Figure 11. Average value, measured humidity levels in the buildings included in this measurement study.

and found a statistically significant linear correlation between relative humidity and absence percent. Absence decreased by $20 \%$ on average when the relative humidity increased from $22 \%$ to $35 \%$. The results regarding bacterial and viral survival demonstrating the following conclusion:

- Incidence of respiratory infections is partly dependent on the indoor occurring relative humidity.

- At the change of the relative humidity from poor or high level to a level between $40 \%$ and $60 \%$ respiratory infections decrease [2].

The epidemiological evidence cannot be regarded as conclusive, because many of the studies are not carefully controlled for possible disturbance factors. The decrease may be due to changes in the aerosols sedimentation rate, decreased survival of airborne transported viruses (and optionally in the survival of viruses, attached to surfaces such as furniture, which are transmitted by direct contact) or to a reduction of man's susceptibility to infection [62]-[64].

The measurements generally identifies lower humidity prevailing in the mechanically ventilated buildings with mean relative humidity $=23.1 \%$ compared with $27.3 \%$ in buildings with natural ventilation. The difference is 4.2 percentage points, and it must be observed that 4.2 to 23.1, after all, is a percentage of the moisture ratio on the entire $18.2 \%$. Measurement results show that the humidity level differs during the daytime. In natural ventilation building the level boosts during the daytime when activities are carried out in the building, compared to the situation in the mechanically ventilated building where it happens that the level even further decline. One must not forget that the average value of natural ventilation buildings, out of people's view of health, will be a bit misleading when the humidity is higher daytime (people in the building) than during the night when it usual- 
ly is not anyone in the building. There is activity in both building types during the day, which should bring the air moisture, but as shown by the study, it happens that the level instead falls in buildings with mechanical ventilation. The only explanation for this is that the ventilation flow was increased from 0 or greatly reduced flow rates, up to $100 \%$ efficiency. If one compares the measurement results presented in Table 1 with the criteria Figure 1 shows, there are the least negative health effects regarding the relative humidity in the range of about $40 \%$ - 60\% relative humidity. Table 1 and Figure 3 show that the average value of the relative humidity in the mechanically ventilated environment is $23.1 \%$ compared with $27.3 \%$ in the environment with natural ventilation. It should be noted again that the environments that are mechanically ventilated, the relative humidity is lower during the day, although the activity is going on in the building as opposed to the environment with natural ventilation where humidity rises during daytime hours due to people staying there.

The situation surrounding the relative humidity, RH, should be highlighted and addressed in an entirely different way than it is today. Given the complaints about health problems perceived in the buildings there is nothing that contradicts that of the low humidity is a cause of these problems often called "sick-building-syndrome" (compare with what is described on the theme page The sick building, Swedish Work Environment Authority) [65]. The number of complaints of skin irritation such as hives (urticaria), skin redness (erythema) and dermatitis among workers in several factories and into a building's switchboard declined after the relative humidity was increased from level 30\%/40\% up to over 50\%. Skin irritation may in part have been caused by an interaction between the low relative humidity and chemicals such as trichlorethylene [66], cyanoacrylate [67], and a methacrylate polymer [68].

\section{References}

[1] Alsmo, T. and Alsmo C. (2013) A Study of Hygiene in Swedish Schools and Pre-Schools-Sources of Air Pollution. Journal of Environmental Protection, 4, 1349-1359.

[2] Arundel, A.V., Sterling, E.M., Biggin, J.H. and Sterling, T.D. (1986) Indirect Health Effects of Relative Humidity in Indoor Environments. Environmental Health Perspectives, 65, 351-356.

[3] Arbetsmiljöverket. The Swedish Work Environment Authority. http://www.av.se/teman/temperatur klimat/kyla/bedomning/

[4] Sveriges meteorologiska och hydrologiska institut. Sweden’s Meteorological and Hydrological Institute. http://www.smhi.se/kunskapsbanken/meteorologi/luftfuktighet-1.3910

[5] Wikipedia http://sv.wikipedia.org/wiki/Luftfuktighet

[6] Meyer, B. (1983) Indoor Air Quality. Addison-Wesley, Reading.

[7] McIntyre, D.A. (1978) Response to Atmospheric Humidity at Comfortable Air Temperature: A Comparison of Three Experiments. The Annals of Occupational Hygiene, 21, 177-190. http://dx.doi.org/10.1093/annhyg/21.2.177

[8] Eng, W.G. (1979) Survey on Eye Comfort In Aircraft: 1. Flight Attendants. Aviation, Space, and Environmental Medicine, 50, 401-404.

[9] Strauss, R.H., McFadden, E.R., Ingram, R.H., Deal, E.C. and Jaeger, J. (1978) Influence of Heat and Humidity on the Airway Obstruction Induced by Exercise in Asthma. Journal of Clinical Investigation, 61, 433-440. http://dx.doi.org/10.1172/JCI108954

[10] Lubart, J. (1962) The Common Cold and Humidity Imbalance. New York State Journal of Medicine, 62, 817-819.

[11] Lubart, J. (1979) Health Care Containment Cost. American Journal of Otolaryngology, 1, 81-83. http://dx.doi.org/10.1016/S0196-0709(79)80011-3

[12] Zeterberg, J.M. (1973) A Review of Respiratory Virology and the Spread of Virulent and Possibly Antigenic Viruses via Air Conditioning Systems. Annals of Allergy, 31, 228-234.

[13] Sale, C.S. (1971) Humidification during the Cold Weather to Assist Perennial Allergic Rhinitis Patients. Annals of Allergy, 29, 356-357.

[14] Ingelstedt, S. (1956) Studies on the Conditioning of Air in the Respiratory Tract. Acta Oto-Laryngologica, Supplementu, 131, 1-80.

[15] Drettner, B., Falck, B. and Simon, H. (1977) Measurements of the Air Conditioning Capacity of the Nose during Normal and Pathological Conditions and Pharmacological Influence. Acta Oto-Laryngologica, 84, 266-277. http://dx.doi.org/10.3109/00016487709123966

[16] Richards, J.H. (1974) Effect of Relative Humidity on the Theological Properties of Bronchial Mucus. American Review of Respiratory Disease, 109, 484-486. 
[17] Buckland, E.E. and Tyrrell, D.A.J. (1962) Loss of Infectivity on Drying Various Viruses. Nature, 195, $1063-1064$. http://dx.doi.org/10.1038/1951063a0

[18] Moe, K. and Shirley, J.A. (1982) The Effect of Relative Humidity and Temperature on the Survival of Human Rotavirus in Faeces. Archives of Virology, 72, 179-186. http://dx.doi.org/10.1007/BF01348963

[19] Couch, R.B. (1981) Viruses and Indoor Air Pollution. Bulletin of the New York Academy of Medicine, 57, 907-921.

[20] Smith, E.B. (1983) Atmospheric Factors Affecting Transmission of Infections. The Practitioner, 227, 1667-1677.

[21] Fitzgerald, J.W. (1975) Approximation Formulas for the Equilibrium Size of an Aerosol Particle as a Function of Its Dry Size and Composition and the Relative Humidity. Journal of Applied Meteorology, 14, 1044-1049. http://dx.doi.org/10.1175/1520-0450(1975)014<1044:AFFTES>2.0.CO;2

[22] Hänel, G. (1977) Humidity Effects on Gravitational Settling and Brownian Diffusion of Atmospheric Particles. Pure and Applied Geophysics, 115, 775-797. http://dx.doi.org/10.1007/BF00881210

[23] Hatch, M.T. and Wolochow, H. (1969) Bacterial Survival: Consequences of the Airborne State. In: Dimmick, R.L. and Akers, A.B., Eds., An Introduction to Experimental Aero Biology, John Wiley and Sons, New York.

[24] LaForce, F.M. (1984) Airborne Infections and Modern Building Technology. In: Berglund, B., Lindvall, T. and Sundell, J., Eds., Proceedings of the 3rd International Conference on Indoor Air Quality and Climate 1: Recent Advances in the Health Sciences and Technology, Swedish Council for Building Research, Stockholm, 109-127.

[25] Wright, D.N., Bailey, G.D. and Hutch, M.J. (1968) Survival of Airborne Mycoplasma as Affected by Relative Humidity. Journal of Bacteriology, 95, 251-252.

[26] Flynn, D.D. and Goldberg, L.J. (1971) Effect of Relative Humidity on Aerosol Persistence of Streptococcus salivarius. Archives of Environmental Health, 23, 40-42. http://dx.doi.org/10.1080/00039896.1971.10665952

[27] Anderson, J.D., Dark, E.A. and Pbto, S. (1968) The Effect of Aerosolization upon Survival and Potassium Retention by Various Bacteria. Microbiology, 52, 99-105. http://dx.doi.org/10.1099/00221287-52-1-99

[28] Rosebury, T. (1947) Experimental Airborne Infection. Williams and Wilkins, Baltimore.

[29] Webb, S.J. (1959) Factors Affecting the Viability of Airborne Bacteria: 1. Bacteria Aerosolized from Distilled Water. Canadian Journal of Microbiology, 5, 649-669. http://dx.doi.org/10.1139/m59-079

[30] Langmuir, A.D. (1980) Changing Concepts of Airborne Infection of Acute Contagious Diseases: A Reconsideration of Classic Epidemiologic Theories. Annals of the New York Academy of Sciences, 353, 35-44. http://dx.doi.org/10.1111/j.1749-6632.1980.tb18903.x

[31] Moffet, H.L. (1980) Clinical Microbiology. J. B. Lippincott, Philadelphia.

[32] Gwaltney, J.M. (1980) Epidemiology of the Common Cold. Annals of the New York Academy of Sciences, 353, 54-60. http://dx.doi.org/10.1111/j.1749-6632.1980.tb18905.x

[33] Knight, V. (1980) Viruses as Agents of Airborne Contamination. Annals of the New York Academy of Sciences, 353, 147-156. http://dx.doi.org/10.1111/j.1749-6632.1980.tb18917.x

[34] Miller, W.S. and Artenstein, M.S. (1967) Aerosol Stability of Three Acute Respiratory Disease Viruses. Experimental Biology and Medicine, 125, 222-227. http://dx.doi.org/10.3181/00379727-125-32054

[35] Davis, G.W, Griesemer, R.A., Shadduck, J.A. and Farrell, R.L. (1971) Effect of Relative Humidity on Dynamic Aerosols of Adenovirus 12. Journal of Applied Microbiology, 21, 676-679.

[36] Hemmes, J.H., Winkler, K.C. and Kool, S.M. (1960) Virus Survival as a Seasonal Factor in Influenza and Poliomyelitis. Nature, 188, 430-431. http://dx.doi.org/10.1038/188430a0

[37] Harper, G.J. (1961) Airborne Micro-Organisms: Survival Tests with Four Viruses. Journal of Hygiene, 59, 479-486. http://dx.doi.org/10.1017/S0022172400039176

[38] Schulman, J.L. and Kilbourne, E.D. (1962) Airborne Transmission of Influenza Virus Infection in Mice. Nature, 182, 1129-1130. http://dx.doi.org/10.1038/1951129a0

[39] Lester, W. (1948) The Influence of Relative Humidity on the Infectivity of Air-Borne Influenza A Virus (PR8 Strain). Journal of Experimental Medicine, 88, 361-367. http://dx.doi.org/10.1084/jem.88.3.361

[40] Schaffer, E.L., Soergel, M.E. and Straube, D.C. (1976) Survival of Airborne Influenza Virus: Effects of Propagating Host, Relative Humidity, and Composition of Spray Fluids. Archives of Virology, 51, 263-273. http://dx.doi.org/10.1007/BF01317930

[41] Wraith, D.G., Cunnington, A.M. and Seymour, W.M. (1979) The Role and Allergenic Importance of Storage Mites in House Dust and Other Environments. Clinical \& Experimental Allergy, 9, 545-561. http://dx.doi.org/10.1111/j.1365-2222.1979.tb00478.x

[42] Korsgaard, J. (1982) Preventive Measures in House-Dust Allergy. American Review of Respiratory Disease, 125, 80- 
84.

[43] Arlian, L.G., Bernstein, I.L. and Gallagher, J.S. (1982) The Prevalence of House Dust Mites, Dermatophagoides spp, and Associated Environmental Conditions in Homes in Ohio. Journal of Allergy and Clinical Immunology, 69, 527532. http://dx.doi.org/10.1016/0091-6749(82)90178-6

[44] Murray, A.B. and Zuk, P. (1979) The Seasonal Variation in a Population of House Dust Mites in a North American City. Journal of Allergy and Clinical Immunology, 64, 266-269. http://dx.doi.org/10.1016/0091-6749(79)90142-8

[45] Arlan, L.G., Brandt, R.L. and Bernstein, R. (1978) Occurrence of House Dust Mites, Dermatophagoides spp. during the Heating Season. Journal of Medical Entomology, 15, 35-42.

[46] Gravesen, S. (1979) Fungi as a Cause of Allergic Disease. Allergy, 34, 135-154.

http://dx.doi.org/10.1111/j.1398-9995.1979.tb01562.x

[47] English, P.T. (1980) Medical Mycology. Edward Arnold, London.

[48] NAS (National Academy of Sciences) (1981) Indoor Pollutants. National Academy Press, Washington DC.

[49] Andersen, I., Lundqvist, G.R. and Molhave, L. (1976) The Effect of Air Humidity and Sulphur Dioxide on Formaldehyde Emissions from a Construction Material (Chipboard). Holzforschung und Holzverwertung, 28, 120-121.

[50] IEC Beak Consultants Ltd. (1983) Indoor Air Quality, Cambridge Sealed Homes, a Report for Ontario Ministry of Municipal Affairs and Housing, IEC Beak, Mississauga, Ontario, October.

[51] Sheppard, D., Wong, W.S. and Uehora, C.F. (1981) Lower Threshold and Greater Bronchomotor Responsiveness of Asthmatic Subjects to Sulfur Dioxide. American Review of Respiratory Disease, 122, 873-878.

[52] Alaire, Y., Ulrich, C.E., Busey, W.M., Krumm, A.A. and MacFarland, H.N. (1972) Long-Term Continuous Exposures to Sulfur Dioxide in Cynomolgus Monkey. Archives of Environmental Health, 24, 115-128. http://dx.doi.org/10.1080/00039896.1972.10666060

[53] US Environmental Protection Agency (1982) Air Quality Criteria for Oxides of Nitrogen. Environmental Criteria and Assessment Office, Research Triangle Park, NC.

[54] Mueller, F., Loeb, L. and Maper, W.H. (1973) Decomposition Rates of Ozone in Living Areas. Environmental Science \& Technology, 7, 342. http://dx.doi.org/10.1021/es60076a003

[55] Farrell, B.R., Kerr, H.D. and Kulle, T.J. (1979) Adaptation in Human Subjects to the Effects of Inhaled Ozone after Repeated Exposure. American Review of Respiratory Disease, 119, 725-730.

[56] Hope-Simpson, R.E. (1958) The Epidemiology of Non-Infectious Diseases. Royal Society of Health Journal, 78, 593.

[57] Gelperin, A. (1973) Humidification and Upper Respiratory Infection Incidence. Heating, Piping, Air Conditioning, 45, 3.

[58] Sale, C.S. (1972) Humidification to Reduce Respiratory Illnesses in Nursery School Children. Southern Medical Journal, 65, 882-885.

[59] Ritzel, G. (1966) Sozialmedizinsche Erhebungen zur Pathogenese und prophylare von Erkaltungskankheiten. Zeitschrift für Präventivmedizin, 11, 9-16. http://dx.doi.org/10.1007/BF02031776

[60] NCHS (National Center for Health Statistics) (1975) Acute Conditions: Incidence and Associated Disability, United States July 1973-June 1974, National Center for Health Statistics, Rockville, Md., DHEW Publ. (HRA) 76-1529.

[61] Green, G.H. (1979) The Effect of Indoor Relative Humidity on Colds. ASHRAE Transactions, 85, 747-757.

[62] Lubart, J. (1962) The Common Cold and Humidity Imbalance. New York State Journal of Medicine, 62, 817-819.

[63] Lubart, J. (1979) Health Care Cost Containment. American Journal of Otolaryngology, 1, 81-83. http://dx.doi.org/10.1016/S0196-0709(79)80011-3

[64] Zeterberg, J.M. (1973) A Review of Respiratory Virology and the Spread of Virulent and Possibly Antigenic Viruses via Air Conditioning Systems. Annals of Allergy, 31, 228-234.

[65] Arbetsmiljöverkets temasida “sjuka hus” The Swedish Work Environment Authorithy, Theme Page "Sick Buildings”. http://www.av.se/teman/sjuka_hus/

[66] Rycroft, R.J.G. and Smith, W.D.L. (1980) Low Humidity Occupational Dermatoses. Contact Dermatitis, 6, 488-492. http://dx.doi.org/10.1111/j.1600-0536.1980.tb05572.x

[67] Calnan, C.D. (1979) Cyanoacrylate Dermatitis. Contact Dermatitis, 5, 165-167. http://dx.doi.org/10.1111/j.1600-0536.1979.tb04830.x

[68] White, I.R. and Rycroft, R.J.G. (1982) Low Humidity Occupational Dermatosis—An Epidemic. Contact Dermatitis, 8, 287-290. http://dx.doi.org/10.1111/j.1600-0536.1982.tb04232.x 
Scientific Research Publishing (SCIRP) is one of the largest Open Access journal publishers. It is currently publishing more than 200 open access, online, peer-reviewed journals covering a wide range of academic disciplines. SCIRP serves the worldwide academic communities and contributes to the progress and application of science with its publication.

Other selected journals from SCIRP are listed as below. Submit your manuscript to us via either submit@scirp.org or Online Submission Portal.
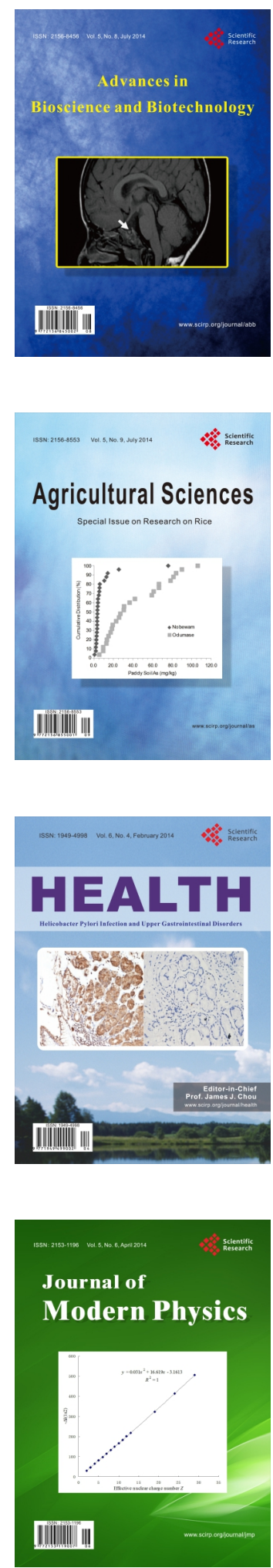
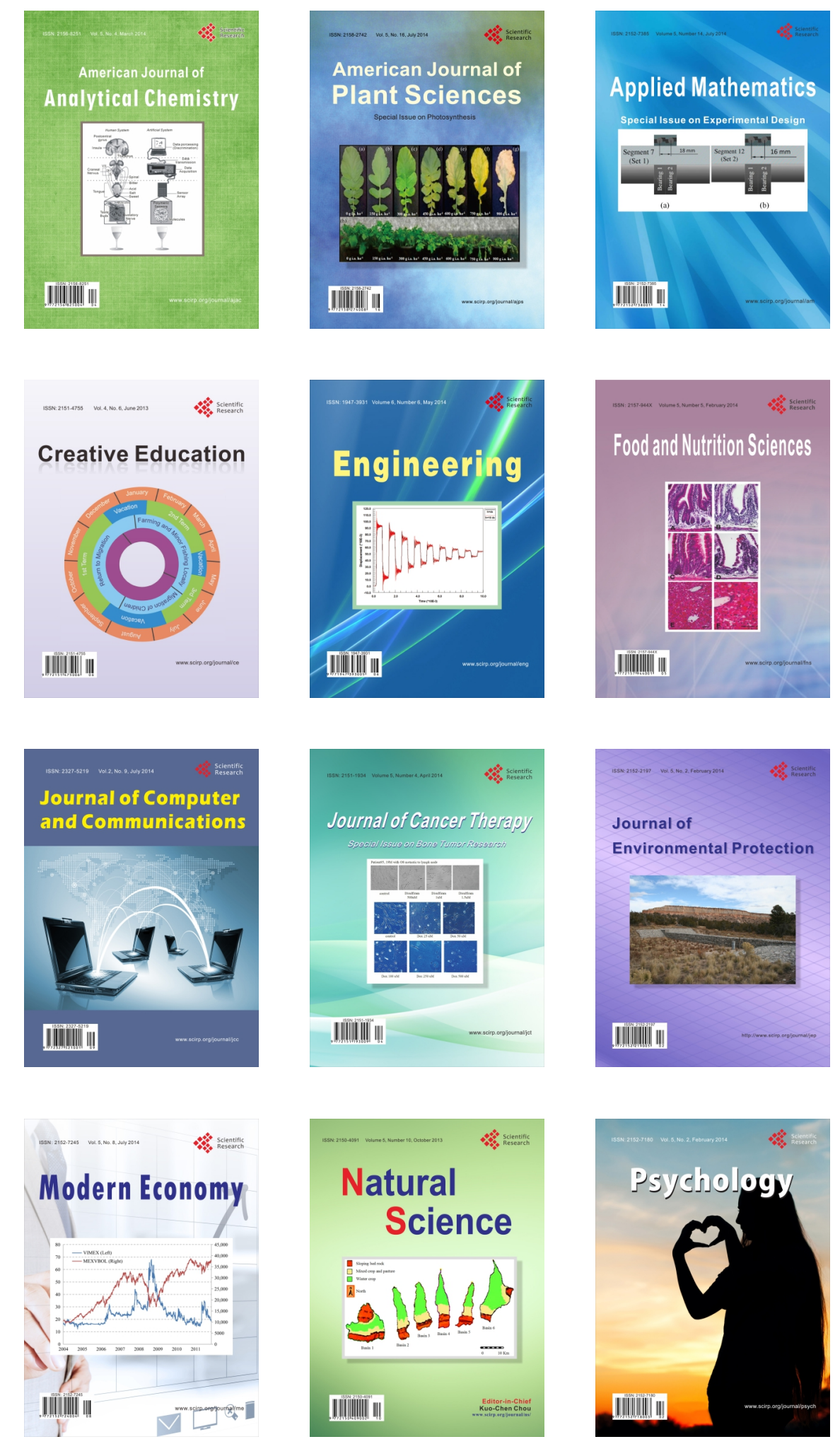